\title{
Resolution of antibiotic mixtures in serum samples by high-voltage electrophoresis
}

\author{
D. S. REEVES AND H. A. HOLT \\ From the Department of Medical Microbiology, Division of Pathology, Southmead Hospital, \\ Bristol BS10 5NB
}

SYNOPSIS The use of high-voltage electrophoresis and bioautography for the separation mixtures of antibiotics received in clinical serum samples is described. The electrophoretic characteristics of 39 antibiotics are given as is the accuracy of the method for quantitating three antibiotics. In screening 189 consecutive serum samples submitted for routine antibiotic assay, undisclosed antibiotics were revealed by the technique in 35 .

The treatment of infection by administering more than one antibiotic simultaneously to patients in hospital is common practice. Increasingly laboratories are being asked to assay sera from such patients, and although it is frequently possible to measure at least one element in a mixture by the use of a selectively resistant organism or by inactivating a component, such procedures are not always available. A further problem is that, in our experience, sera for assay sometimes contain antibiotics of which the laboratory is not made aware and which can adversely affect assay results. The clinician requesting the investigation may not always know, or just simply forgets, about antibiotics which a patient is receiving or has recently received. Therefore a technique is needed to detect the presence of extraneous antibiotics and to identify them. If the technique could be made quantitative then this would be an advantage.

With these criteria in mind we adapted the wellknown technique of high-voltage electrophoresis to resolving antibiotic mixtures. To our knowledge its adaptation for use with the type of concentrations found in the sera of patients on treatment has not previously been described. Using this method we determined the relative mobility of 39 antimicrobial agents used in clinical practice and examined the conditions for their optimal detection and also the limits of detection. We also determined the accuracy of quantitative assay of three antibiotics. Finally, a retrospective survey was made of sera submitted for antibiotic assay from patients to determine the frequency of extraneous antimicrobial agents.

Received for publication 7 January 1975.

\section{Methods}

\section{MATERIALS}

The sources of the antibiotics used are shown in table I. They were prepared for electrophoresis as solutions in distilled water or pooled human serum.

Samples from patients examined for their antibiotic content were those which had been received for assay, mostly of gentamicin, in controlling therapy. They were stored at $-20^{\circ} \mathrm{C}$ for examination in batches.

\section{SEPARATION OF ANTIBIOTICS}

The method used was adapted from that described by Lightbown and de Rossi (1965). The apparatus (Stogate Instruments Ltd) (fig 1) used consisted of a carefully levelled, water-cooled bed on which the glass platten carrying the agar was placed. The water supply to the bed was from a mixer-tap, allowing the temperature of the platten to be varied. At each end of the platten there were two buffer boxes, the distal ones containing the platinum electrodes $(25 \mathrm{~cm}$ of $0.38 \mathrm{~mm}$ diameter wire). The platten and boxes were all contained in a Perspex safety-cabinet with a lid which operated micro-switches controlling the output of the power pack. The power pack (Stogate Instruments Ltd) was capable of delivering a maximum of $200 \mathrm{~mA}$ and 2500 volts.

Electrophoresis was performed in $0.9 \%$ agarose (BDH) in pH 5.6 buffer. ${ }^{1}$ Seventy millilitres of $1.8 \%$ agarose in water was melted, and an equal volume of buffer was added. A rectangular sheet of glass was

'Tris-(hydroxy-methyl)-aminomethane $27.21 \mathrm{~g}$

Maleic acid $26.10 \mathrm{~g}$

Distilled water to adjust to $\mathrm{pH} 5 \cdot 6$ with $5 \mathrm{~N} \mathrm{NaOH}$. 


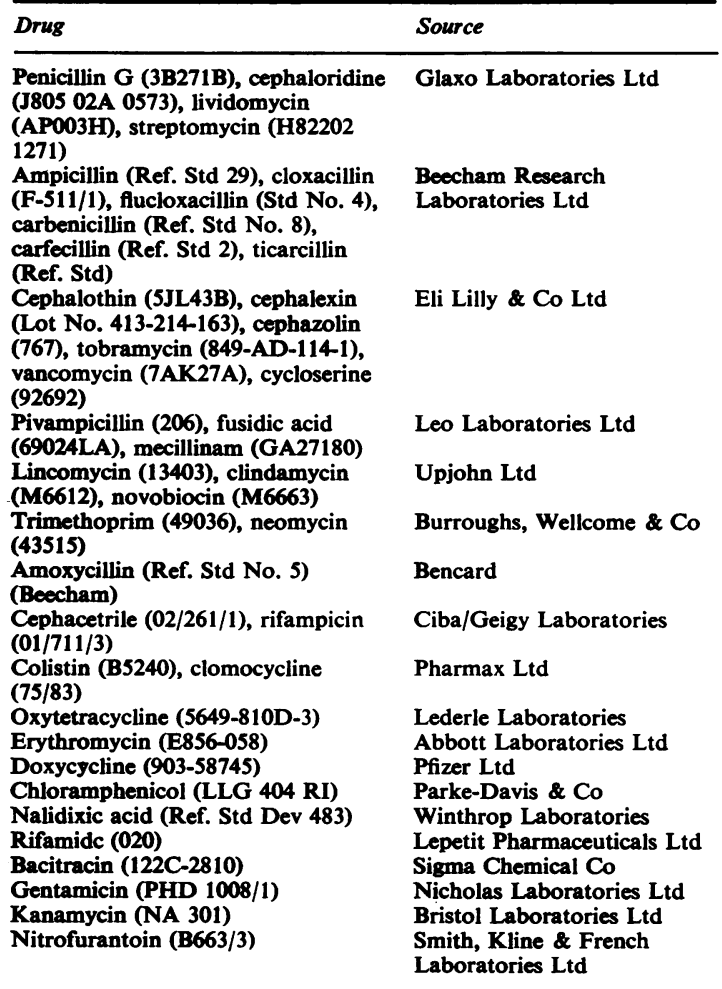

Table I Sources of antibiotics used (with batch no. if known)

placed on the platten and warmed. A metal frame held by 'bulldog' clips was placed temporarily on the glass to retain the molten agarose and was sealed to it with a little molten agarose. The rest of the agarose was then poured to give a layer of even depth of $1.3 \mathrm{~mm}$. The frame was removed when the agarose was set. Sample volumes of $10 \mu \mathrm{l}$ were placed in wells cut with a $4 \mathrm{~mm}$ diameter cork borer. The buffer boxes each contained $600 \mathrm{ml}$ of halfstrength buffer and were connected to the agar and each other with presoaked lint wicks running the full width of the plate. After closing the lid of the safety box the electrophoresis was run normally for 40 minutes at a constant current of $190 \mathrm{~mA}$, which gave a starting potential of 800 volts. The time varied according to the degree of separation required. During electrophoresis cold water at $18-20^{\circ} \mathrm{C}$ from the mains was run through the bed.

\section{DETECTION OF ANTIBIOTICS IN RUNNING LAYER}

The positions and amounts of antibiotics in the running layer were determined by adding a seeded layer of agar onto the agarose after the completion of the electrophoresis. The seed layer was usually 200 ml of Oxoid DST agar incorporated with Bacillus subtilis (NCTC 6633) or Staphylococcus aureus (NCTC 6571). This was prepared on a similar glass platten to the running layer during electrophoresis and, when set, was slid carefully onto the running layer making sure that it was in good contact and alignment with it. If quantitative results were required the seed layer was poured directly onto the running layer to minimize the distortion inevitably encountered in the first process. In this case only a spore-seeded agar could be used because of the higher pouring temperature required. The seed layers were adjusted to have a $\mathrm{pH}$ of either 7.9 or 6.0 according to the optimal requirements for detection or estimation of the antibiotic.

Other variations used were Escherichia coli (NCTC 10418) as indicator organism when the drugs

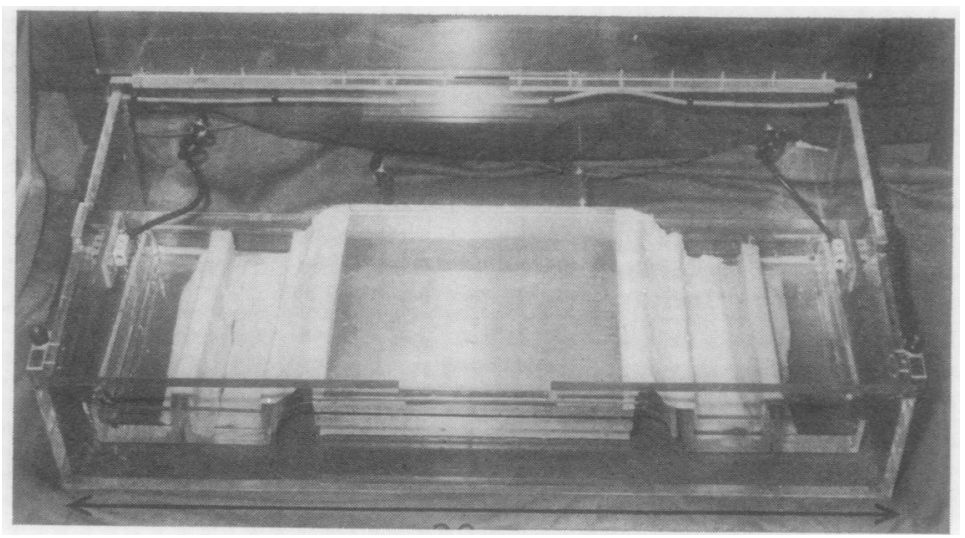

Fig 1 Electrophoresis bed and buffer boxes with platten and wicks in place. Lid of safety cabinet is open. 
detected were inactive against Gram-positive species, and the use of Wellcome Wellcotest agar (pH 7.3) for the seed layer when sulphonamides and trimethoprim were investigated.

It was found that some antibiotics, particularly the aminoglycosides, ran as 'streaks' in the agarose. The addition of sodium chloride to a final concentration of $1 \%$ to the running layer corrected this, the zones being round or pear-shaped under these conditions. However, electrophoresis was prolonged because the increased conductivity of the agar limited the voltage available from the power source.

Finally, after the application of the seed layer, the frame was replaced, the seed layer surface sterilized with ultraviolet light, and a metal lid added for overnight incubation at $37^{\circ} \mathrm{C}$.

\section{SCREENING OF SERA FOR UNSUSPECTED}

ANTIBIOTICS

When samples from patients were screened, sera were initially electrophoresed in duplicate on two separate plates, and a seed layer of different $\mathrm{pH}$ was used on the two plates. It was soon noticed that antibiotics which migrated to the anode were detected optimally by the acid agar while those which migrated to the cathode were best detected by an alkaline agar. Two alternative methods were therefore used subsequently to save running samples on two plates.

In the first method the running layer was divided by laying a glass rod across the width of the plate down the line of application wells. The plate was warmed slightly, and a seed layer at $\mathrm{pH} 6.0$ was poured onto the anode end and a pH 7.9 seed layer was poured onto the cathode end. This method was used routinely.

A second method was used when the presence of antibiotics with a low relative mobility $\left(R_{M}\right)$ was anticipated, since the presence of the glass rod in the first method made zones near the application wells difficult to read. Instead, a seed layer with a continuous $\mathrm{pH}$ gradient was prepared by pouring agar of pH 5.0 first on an inclined plate to give a layer of wedge-shaped agar. After the agar had set the plate was levelled and an upper layer of agar of $\mathrm{pH} 9$ was poured to give a complementary wedge. When cool, the pair of seed layers were then slid onto the running layer correctly orientated so that the agar with the high $\mathrm{pH}$ was at the cathodal end.

\section{RECORDING}

All zones were measured by hand with regard to both size and distance from their origin, that is, from the centre of the well to the centre of the zone. Plates were also photographed on a specially constructed box giving dark-ground illumination. The $R_{M}$ of a drug was taken as its mobility proportional to that of penicillin (to the anode end; $R_{M}$ value 1.0 ) or streptomycin (to the cathode end; $R_{M}$ value $1 \cdot 0$ ), and thus these drugs were put as markers on all plates. Distances were measured from the centre of the application well to the centre of the zone of inhibition. In the case of pear-shaped and streaked zones the point chosen arbitrarily was the centre of the smallest radius furthest from the well. For quantitative estimations areas were calculated from measurements taken using a magnifying zone-reader (Leebrook Scientific Co Ltd). In the case of round zones the area was taken to be $\Pi \mathrm{r}^{2}$; for oval zones the formula used was $\Pi\left(\frac{a}{2}\right)\left(\frac{b}{2}\right)$, where $a$ was the longest dimension and $b$ the shortest ; for pear-shaped zones the formula used was $4 / 3 b(a+b)-\left(\Pi / 2 b^{2}\right)$ where $a$ and $b$ were as for an oval. The veracity of this last formula was checked by tracing around the magnified zones on the zone-reader using cleared, old $x$-ray film, cutting out the zones and weighing them. The areas of streaked zones were not measured since high salt-agar was used for the quantitation of the antibiotics which behaved in this way.

QUANTITATION OF ANTIBIOTICS

The accuracy of quantitation of three antibiotics was assessed by making up a series of 10 sera for each drug containing known concentrations of antibiotics. Each serum was assayed ten times and the $95 \%$ confidence limits for the assay were calculated. The antibiotics chosen were kanamycin and cephaloridine since they gave oval and round zones respectively using the routine running agarose, and gentamicin because the high-salt content running agarose was used.

\section{RESOLUTION OF SERA SUBMITTED FOR}

ROUTINE ASSAYS

One hundred and eighty-nine consecutive sera sent to the laboratory for routine assays were examined for the presence of antibiotics other than that requested. Almost all were for gentamicin assay. In many cases the presence of other antibiotics had been notified to the laboratory at the time of the original assay. When additional drugs were found their identification was made as far as possible by their $\mathbf{R}_{\mathbf{M}}$ value and susceptibility to $\beta$-lactamase. Confirmation of the identity of the spurious drug was by retrospective search through the patient's notes.

\section{Results}

QUALITATIVE IDENTIFICATION

The determined $\mathbf{R}_{\mathbf{M}}$ value, direction of travel, and 


\begin{tabular}{|c|c|c|c|c|c|c|}
\hline \multirow[t]{2}{*}{ Antibiotic } & \multicolumn{3}{|l|}{$\boldsymbol{R}_{M}$ in water } & \multicolumn{3}{|l|}{$R_{M}$ in serum } \\
\hline & No. of Observations & Mean & $S D$ & No. of Observations & Mean & $S D$ \\
\hline $\begin{array}{l}\text { Amoxacillin } \\
\text { Ampicillin } \\
\text { Carbenicillin }\end{array}$ & $\begin{array}{r}9 \\
34 \\
14\end{array}$ & $\begin{array}{l}0 \cdot 12 \\
0 \cdot 10 \\
1.97\end{array}$ & $\begin{array}{l}0.02 \\
0.01 \\
0.08\end{array}$ & $\begin{array}{r}5 \\
29 \\
8\end{array}$ & $\begin{array}{l}0.09 \\
0.08 \\
1.93\end{array}$ & $\begin{array}{r}<0.01 \\
0.02 \\
0.03\end{array}$ \\
\hline Carfecillin & 15 & $0 \cdot 8$ & 0.01 & 3 & $0 \cdot 75$ & 0.03 \\
\hline $\begin{array}{l}\text { Cloxacillin } \\
\text { Flucloxacillin } \\
\text { Mecillinam } \\
\text { Pivampicillin }\end{array}$ & $\begin{array}{l}25 \\
14 \\
14 \\
25\end{array}$ & $\begin{array}{l}0.90 \\
0.89 \\
0.15 \\
0.69\end{array}$ & $\begin{array}{l}0.03 \\
0.04 \\
0.01 \\
0.04\end{array}$ & $\begin{array}{r}14 \\
8 \\
24 \\
14\end{array}$ & $\begin{array}{l}0.74 \\
0.75 \\
0 \cdot 14 \\
0.61\end{array}$ & $\begin{array}{l}0.05 \\
0.02 \\
0.01 \\
0.03\end{array}$ \\
\hline $\begin{array}{l}\text { Ticarcillin } \\
\text { Penicillin }\end{array}$ & $\begin{array}{l}8 \\
\text { Taken as } 1 \cdot 0\end{array}$ & 1.97 & 0.02 & $\begin{array}{r}5 \\
23\end{array}$ & $\begin{array}{l}1.97 \\
0.97\end{array}$ & $\begin{array}{r}<0.01 \\
0.01\end{array}$ \\
\hline
\end{tabular}

Table II Results of high-voltage electrophoresis of penicillins

${ }^{1}$ Minimum concentration detectable in routine system

${ }^{2}$ Concentration producing maximum convenient zone size in the system as described

\begin{tabular}{|c|c|c|c|c|c|c|}
\hline \multirow[t]{2}{*}{ Antibiotic } & \multicolumn{3}{|l|}{$R_{M}$ in water } & \multicolumn{3}{|l|}{$R_{M}$ in serum } \\
\hline & No. of Observations & Mean & $S D$ & No. of Observations & Mean & $S D$ \\
\hline $\begin{array}{l}\text { Cephacetrile } \\
\text { Cephalexin } \\
\text { Cephaloridine } \\
\text { Cephalothin } \\
\text { Cephazolin }\end{array}$ & $\begin{array}{r}10 \\
7 \\
11 \\
9 \\
12\end{array}$ & $\begin{array}{l}1 \cdot 0 \\
0 \cdot 11 \\
0 \cdot 16 \\
0 \cdot 94 \\
0 \cdot 87\end{array}$ & $\begin{array}{l}0.01 \\
0.02 \\
0.01 \\
0.03 \\
0.02\end{array}$ & $\begin{array}{r}6 \\
6 \\
15 \\
4 \\
3\end{array}$ & $\begin{array}{l}1.02 \\
0.09 \\
0.16 \\
0.89 \\
0.76\end{array}$ & $\begin{array}{r}<0.01 \\
0.01 \\
0.02 \\
0.02 \\
0.02\end{array}$ \\
\hline
\end{tabular}

Table III Results of high-voltage electrophoresis of cephalosporins

${ }^{1}$ Minimum concentration detectable in routine system

${ }^{2}$ Concentration producing maximum convenient zone size in the system as described

\begin{tabular}{|c|c|c|c|c|c|c|}
\hline \multirow[t]{2}{*}{ Antibiotic } & \multicolumn{3}{|l|}{$\boldsymbol{R}_{M}$ in water } & \multicolumn{3}{|l|}{$\boldsymbol{R}_{M}$ in serum } \\
\hline & No. of Observations & Mean & $S D$ & No. of Observations & Mean & $S D$ \\
\hline \multicolumn{7}{|l|}{ In high-salt agarose } \\
\hline Gentamicin & 6 & 0.95 & 0.06 & 13 & 0.83 & 0.04 \\
\hline Neomycin & 6 & $1 \cdot 12$ & 0.07 & 14 & 0.88 & 0.06 \\
\hline Tobramycin & 9 & $1 \cdot 03$ & 0.05 & 13 & 0.82 & $0 \cdot 1$ \\
\hline \multicolumn{7}{|l|}{ In normal agarose } \\
\hline Kanamycin & 12 & 0.96 & 0.02 & 6 & 0.93 & 0.03 \\
\hline Lividomycin & 10 & 0.85 & 0.03 & 20 & $0 \cdot 80$ & 0.01 \\
\hline Streptomycin & Taken as 1 & & & 19 & 0.96 & 0.03 \\
\hline Vancomycin & 4 & $0 \cdot 27$ & $<0.01$ & 3 & $0 \cdot 21$ & $<0.01$ \\
\hline
\end{tabular}

Table IV Results of high-voltage electrophoresis of aminoglycosides

${ }^{1}$ Minimum concentration detectable in routine system

${ }^{2}$ Concentration producing maximum convenient zone size in the system as described

'Give smear-shaped zones in normal agarose

optimal condition for the limits of concentration in serum are given for various groups of antibiotics in tables II, III, IV, and V. Mean $\mathbf{R}_{\mathbf{M}}$ values are given for each drug in water and pooled human serum, together with the standard deviations of the observed values. In many instances the variation was remarkably small. A demonstration of several different mobilities and zone shapes is shown (fig 2). For the large majority of antibiotics the $R_{M}$ value was independent of the concentration within the limits given. Exceptions were antibiotics which 'smeared' in the normal running agarose; when run in highsalt agarose the zones became oval and the $R_{M}$ values were again independent of the concentration. Increasing the salt concentration from $1 \%$ to $2 \%$ usually failed to produce completely round zones. 


\begin{tabular}{|c|c|c|c|c|c|}
\hline \multirow[t]{2}{*}{ Shape of Zone } & \multirow[t]{2}{*}{ Direction of Travel } & \multicolumn{2}{|c|}{ Detectable $(\mu \mathrm{g} / \mathrm{ml})$} & \multirow{2}{*}{$\begin{array}{l}\text { pH of Seed } \\
\text { Layer }\end{array}$} & \multirow[t]{2}{*}{ Organism in Seed Layer } \\
\hline & & $\operatorname{Min}^{1}$ & $\operatorname{Max}^{2}$ & & \\
\hline Round & Cathode & $0 \cdot 5$ & 20 & 7.9 & B. subtilis \\
\hline Round & Cathode & 0.5 & 10 & $7 \cdot 9$ & B. subtilis \\
\hline Round & Anode & $5 \cdot 0$ & 50 & $6 \cdot 0$ & $\begin{array}{l}\text { B. subtilis. Carbenicillin breaks down to penicillin, more rapidly } \\
\text { in water than serum }\end{array}$ \\
\hline Round & Anode & $2 \cdot 0$ & 50 & $6 \cdot 0$ & $\begin{array}{l}\text { B. subtilis. In serum carfecillin breaks down to carbenicillin then } \\
\text { to penicillin }\end{array}$ \\
\hline Round & Anode & $5 \cdot 0$ & 50 & $6 \cdot 0$ & B. subtilis \\
\hline Round & Anode & $5 \cdot 0$ & 50 & $6 \cdot 0$ & B. subtilis \\
\hline Pear & Cathode & 50 & 500 & 7.9 & B. subtilis \\
\hline Pear & Cathode & $1 \cdot 0$ & 50 & $7 \cdot 9$ & $\begin{array}{l}B \text {. subtilis. Pivampicillin breaks down to ampicillin, more } \\
\text { rapidly in serum than in water }\end{array}$ \\
\hline Round & Anode & $2 \cdot 0$ & 50 & $6 \cdot 0$ & B. subtilis. As carbenicillin \\
\hline Round & Anode & 0.3 & 20 & $6 \cdot 0$ & B. subtilis \\
\hline
\end{tabular}

Table-continued

\begin{tabular}{|c|c|c|c|c|c|}
\hline \multirow[t]{2}{*}{ Shape of Zone } & \multirow[t]{2}{*}{ Direction of Travel } & \multicolumn{2}{|c|}{ Detectable $(\mu \mathrm{g} / \mathrm{ml})$} & \multirow{2}{*}{$\begin{array}{l}\text { pH of Seed } \\
\text { Layer }\end{array}$} & \multirow[t]{2}{*}{ Organism in Seed Layer } \\
\hline & & $\operatorname{Min}^{1}$ & $\operatorname{Max}^{2}$ & & \\
\hline $\begin{array}{l}\text { Round } \\
\text { Round } \\
\text { Round } \\
\text { Round } \\
\text { Round }\end{array}$ & $\begin{array}{l}\text { Anode } \\
\text { Cathode } \\
\text { Cathode } \\
\text { Anode } \\
\text { Anode }\end{array}$ & $\begin{array}{c}5 \cdot 0 \\
10 \\
2 \cdot 0 \\
2 \cdot 0 \\
5 \cdot 0\end{array}$ & $\begin{array}{r}100 \\
100 \\
25 \\
100 \\
100\end{array}$ & $\begin{array}{l}6 \cdot 0 \\
7.9 \\
7.9 \\
6.0 \\
6.0\end{array}$ & $\begin{array}{l}\text { B. subtilis } \\
\text { B. subtilis } \\
\text { B. subtilis } \\
\text { B. subtilis } \\
\text { B. subtilis }\end{array}$ \\
\hline
\end{tabular}

Table-continued

\begin{tabular}{|c|c|c|c|c|c|}
\hline \multirow[t]{2}{*}{ of Zon } & \multirow[t]{2}{*}{ Direction of Travel } & \multicolumn{2}{|c|}{ Detectable $(\mu \mathrm{g} / \mathrm{ml})$} & \multirow{2}{*}{$\begin{array}{l}\text { pH of Seed } \\
\text { Layer }\end{array}$} & \multirow[t]{2}{*}{ Organism in Seed Layer } \\
\hline & & $\operatorname{Min}^{1}$ & $\operatorname{Max}^{2}$ & & \\
\hline \multicolumn{6}{|l|}{ In high-salt agarose } \\
\hline Pears & Cathode & $2 \cdot 5$ & 50 & 7.9 & B. subtilis \\
\hline Pear $^{3}$ & Cathode & 0.5 & 50 & $7 \cdot 9$ & B. subtilis \\
\hline Round ${ }^{3}$ & Cathode & $2 \cdot 0$ & 50 & $7 \cdot 9$ & B. subtilis \\
\hline \multicolumn{6}{|c|}{ In normal agarose } \\
\hline Pear & Cathode & $5 \cdot 0$ & 100 & $7 \cdot 9$ & B. subtilis \\
\hline Pear & Cathode & 50 & 500 & 7.9 & B. subtilis \\
\hline Round & Cathode & 2 & 50 & $7 \cdot 9$ & Staph. aureus \\
\hline Round & Cathode & $5 \cdot 0$ & 50 & $7 \cdot 9$ & B. subtilis \\
\hline
\end{tabular}

Table-continued

For the accurate determination of $R_{M}$ values it was essential to have a number of marker-antibiotic (penicillin or streptomycin) zones across the width of the plate since they rarely ran in a straight line but produced a slightly bowed 'front'. This was presumably due to a greater current flow in the more central portion of the running agarose, giving a higher potential difference and thus greater mobility.
The extreme edges of the running agarose were avoided since results were often unreliable there.

Most antibiotics gave single zones but there were exceptions. Colistin was a notable example, giving a combination of several oval and smear-shaped zones, as might be expected. Carbenicillin gave zones in the penicillin region, as did ticarcillin. Esters of penicillins (carfecillin and pivampicillin) 


\begin{tabular}{|c|c|c|c|}
\hline \multirow[t]{2}{*}{ Antibiotic } & \multicolumn{3}{|l|}{$\boldsymbol{R}_{M}$ in water } \\
\hline & No. of Observations & Mean & $S D$ \\
\hline Bacitracin & 9 & $0 \cdot 37$ & \\
\hline Chloramphenicol & 9 & $0 \cdot 15$ & 0 \\
\hline Clindamycin & 17 & 0.80 & 0 \\
\hline Clomocycline & 3 & 0.09 & $<0$ \\
\hline Colistin & 3 & $0 \cdot 30$ & \\
\hline Cycloserine & 7 & $0 \cdot 17$ & \\
\hline Doxycycline & 10 & 0.09 & 0 \\
\hline Erythromycin & 13 & 0.64 & \\
\hline Fusidic acid & 3 & 0.57 & $<0$ \\
\hline Lincomycin & 5 & 0.82 & \\
\hline Nalidixic acid & 16 & $0 \cdot 30$ & \\
\hline Nitrofurantoin & 15 & $0 \cdot 10$ & \\
\hline Novobiocin & 4 & 0.53 & \\
\hline Oxytetracycline & 11 & $0 \cdot 12$ & \\
\hline Rifampicin & 15 & $0 \cdot 22$ & \\
\hline Rifamycin & 16 & $0 \cdot 32$ & \\
\hline Trimethoprim & 7 & 0.87 & \\
\hline \multicolumn{4}{|c|}{ Table V Results of high-voltage electrophoresis of remaini } \\
\hline \multicolumn{4}{|c|}{$\begin{array}{l}{ }^{1} \text { Minimum concentration detectable in routine system } \\
{ }^{2} \text { Concentration producing maximum convenient zone size in the system }\end{array}$} \\
\hline \multicolumn{4}{|c|}{$\begin{array}{l}\text { gave zones in the region of their parent antibiotic } \\
\text { as well as those of the ester, a phenomenon more } \\
\text { prominent with serum samples. Carfecillin thus } \\
\text { gave three zones on occasions-that of the ester, } \\
\text { that of carbenicillin, and that of penicillin. }\end{array}$} \\
\hline
\end{tabular}

On 10 occasions sera from patients on ampicillin with impaired renal function gave zones in the penicillin region although careful checking failed to show that the patient had received penicillin. The zones were presumably some product of ampicillin

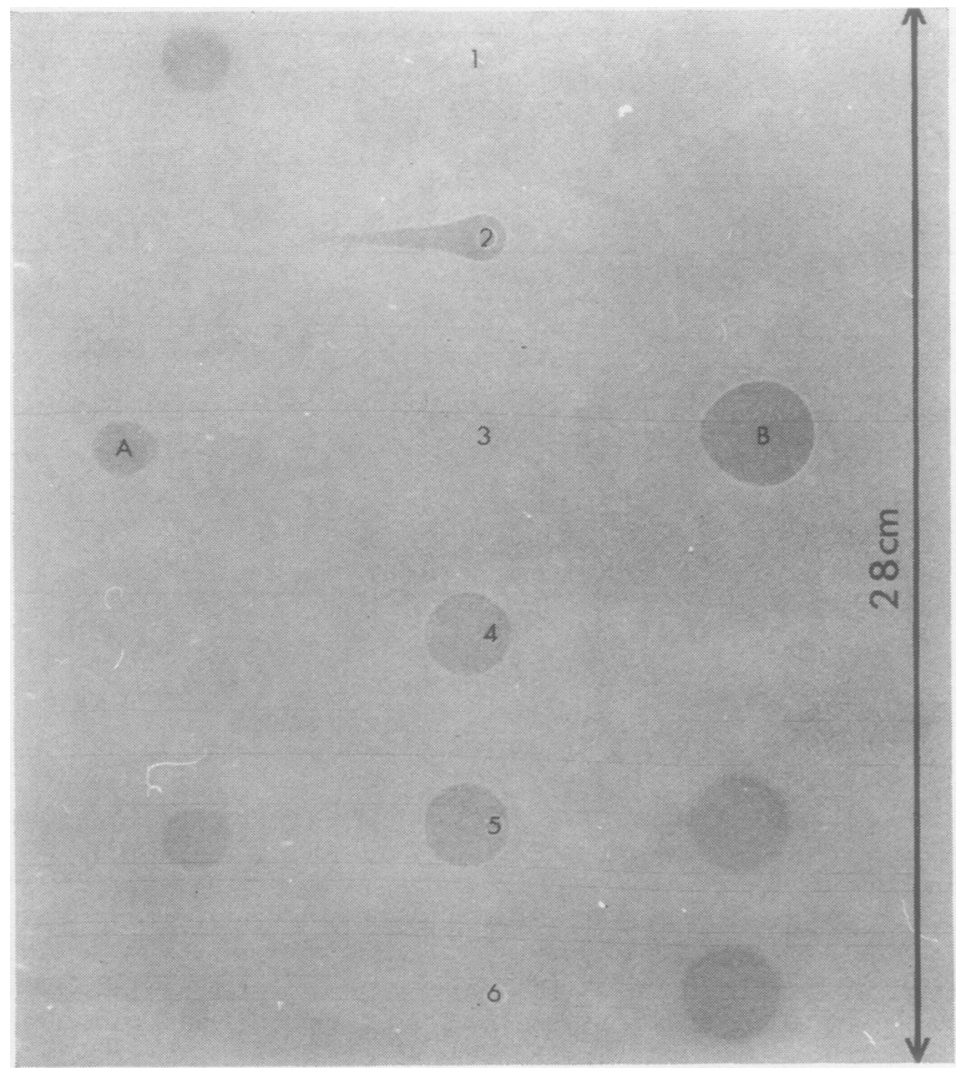

Fig 2 Demonstration separation of antibiotics to show typical mobilities and zone shapes. The wells contained: (1) clindamycin $30 \mu \mathrm{g} / \mathrm{ml}$, (2) gentamicin $10 \mu \mathrm{g} / \mathrm{ml}$, (3) penicillin $5 \mu \mathrm{g} / \mathrm{ml}$ (anodal; B) and streptomycin $25 \mu \mathrm{g} / \mathrm{ml}$ (cathodal; $A$ ), (4) ampicillin $10 \mu \mathrm{g} / \mathrm{ml}$, (5) clindamycin $30 \mu \mathrm{g} / \mathrm{ml}$, ampicillin 10 $\mu \mathrm{g} / \mathrm{ml}$, and cephalothin $10 \mu \mathrm{g} / \mathrm{ml}$, and (6) cephalothin $10 \mu \mathrm{g} / \mathrm{ml}$. 


\begin{tabular}{|c|c|c|c|c|c|}
\hline \multirow[t]{2}{*}{ Shape of Zone } & \multirow[t]{2}{*}{ Direction of Travel } & \multicolumn{2}{|c|}{ Detectable $(\mu \mathrm{g} / \mathrm{ml})$} & \multirow{2}{*}{$\begin{array}{l}\text { pH of Seed } \\
\text { Layer }\end{array}$} & \multirow[t]{2}{*}{ Organism in Seed Layer } \\
\hline & & $\operatorname{Min}^{1}$ & $\operatorname{Max}^{2}$ & & \\
\hline $\begin{array}{l}\text { Round } \\
\text { Round } \\
\text { Round } \\
\text { Pear } \\
\text { Oval } \\
\text { Round } \\
\text { Oval } \\
\text { Round } \\
\text { Oval } \\
\text { Round } \\
\text { Oval } \\
\text { Round } \\
\text { Pear } \\
\text { Round/oval } \\
\text { Oval } \\
\text { Smear/round } \\
\text { Round }\end{array}$ & $\begin{array}{l}\text { Cathode } \\
\text { Cathode } \\
\text { Cathode } \\
\text { Cathode } \\
\text { Anode } \\
\text { Cathode } \\
\text { Cathode } \\
\text { Cathode } \\
\text { Anode } \\
\text { Cathode } \\
\text { Anode } \\
\text { Cathode } \\
\text { Anode } \\
\text { Cathode } \\
\text { Cathode } \\
\text { Anode } \\
\text { Cathode }\end{array}$ & $\begin{array}{c}20 \\
20 \\
1 \cdot 0 \\
10 \cdot 0 \\
50 \\
200 \\
3 \cdot 0 \\
1 \cdot 0 \\
2 \cdot 0 \\
2 \cdot 0 \\
5 \cdot 0 \\
50 \\
10 \cdot 0 \\
10 \cdot 0 \\
0 \cdot 4 \\
2 \cdot 0 \\
2 \cdot 0\end{array}$ & $\begin{array}{c}200 \\
100 \\
50 \\
50 \\
500 \\
2500 \\
50 \\
50 \\
20 \\
40 \\
50 \\
500 \\
100 \\
50+ \\
20 \\
50 \\
40\end{array}$ & $\begin{array}{l}7.9 \\
7.9 \\
7.9 \\
7.9 \\
6.0 \\
7.9 \\
7.9 \\
7.9 \\
6.0 \\
7.9 \\
6.0 \\
7.9 \\
6.0 \\
7.9 \\
7.9 \\
6.0 \\
7.9\end{array}$ & $\begin{array}{l}\text { Staph. aureus } \\
\text { B. subtilis } \\
\text { B. subtilis } \\
\text { B. subtilis } \\
\text { E. coli. More than one zone in serum } \\
\text { E. coli } \\
\text { B. subtilis } \\
\text { B. subtilis } \\
\text { Staph. aureus } \\
\text { Staph. aureus } \\
\text { E. coli } \\
\text { E. coli } \\
\text { Staph. aureus } \\
\text { B. subtilis } \\
\text { B. subtilis } \\
\text { B. subtilis. } \mathbf{R}_{M} \text { values on salt agarose } \\
\text { B. subtilis }\end{array}$ \\
\hline
\end{tabular}

Table-continued

metabolism or breakdown which had been retained because of renal failure. They had a different $R_{M}$ from 6-amino penicillanic acid.

\section{QUANTITATION OF ANTIBIOTICS}

The accuracy of assay of the three antibiotics repeatedly tested is given in table VI. Each of the ten concentrations of each antibiotic was assayed ten times, and the percentage error of each estimation from the true value was calculated. The overall mean percentage error and the $95 \%$ confidence limits were then calculated for the assay of each antibiotic. In a number of experiments with mixtures of antibiotics the single components gave the same potency whether run separately or in a mixture.

\begin{tabular}{lccl}
\hline & $\begin{array}{l}\text { Range of } \\
\text { Concentrations } \\
(\mu \mathrm{g} / \mathrm{m} l)\end{array}$ & $\begin{array}{l}\text { Mean } \\
\text { Percentage } \\
\text { Error }\end{array}$ & $\begin{array}{l}95 \% \\
\text { Confidence } \\
\text { Limits }\end{array}$ \\
\hline Cephaloridine & $2 \cdot 5-10$ & 0 & $\pm 10 \%$ \\
Kanamycin & $10-40$ & -3 & $\pm 16 \%$ \\
Gentamicin & $2 \cdot 5-10$ & -3 & $\pm 26 \%$
\end{tabular}

Table VI Accuracy of quantitative antibiotic assay by method described

\section{DETECTION OF UNDISCLOSED ANTIBIOTICS}

Antibiotics other than those disclosed were detected in 35 sera out of the 189 sera submitted for routine assays from 104 patients (table VII).

\section{QUANTITATION OF MIXTURES}

Apart from the detection of undisclosed antibiotics the technique was of use in the detection and quantitation or semiquantitation of mixtures such as fusidic acid and lincomycin; fusidic acid and flucloxacillin; gentamicin, clindamycin, and penicillin G; gentamicin with lincomycin and ampicillin;

\begin{tabular}{lll}
\hline Antibiotic & & $\begin{array}{l}\text { No. of } \\
\text { Sera }\end{array}$ \\
\cline { 1 - 2 } Disclosed & Undisclosed and Confirmed & \\
\hline Gentamicin & Ampicillin & 11 \\
Gentamicin & Penicillin & 5 \\
Gentamicin & Ampicillin + lincomycin & 2 \\
Gentamicin & Co-trimoxazole & 2 \\
Gentamicin & Clindamycin & 2 \\
Gentamicin & Cephalothin & 1 \\
Gentamicin & Cephalexin & 1 \\
Gentamicin & Carbenicillin & 1 \\
Gentamicin & Cloxacillin & 1 \\
Gentamicin & Flucloxacillin & 1 \\
Gentamicin & Penicillin + clindamycin & 1 \\
Gentamicin & Ampicillin + cloxacillin & 1 \\
Gentamicin + ampicillin & Penicillin & 1 \\
Gentamicin + lincomycin & Ampicillin & 2 \\
penicillin & Penicillin & 2 \\
Ampicillin & Neomycin + ampicillin & 1 \\
Total & & 35 \\
\hline
\end{tabular}

Table VII Undisclosed antibiotics found in 189 sera examined

gentamicin with ampicillin, trimethoprim, and sulphamethoxazole; and gentamicin with neomycin and ampicillin. When we were satisfied that no chemical interaction had taken place between antibiotics before electrophoresis, experimental determination of antibiotics singly and in mixtures always gave the same results. For example, cloxacillin and fusidic acid gave identical qualitative and quantitative results when determined from a mixture as when run separately.

\section{Discussion}

With the increasing complexity of modern therapy patients are frequently given more than one antibiotic either sequentially or concurrently. Such treatment poses two main problems for a laboratory receiving samples for assay by microbiological 
methods.

The first is the quantitative measurement of one or more antibiotics in the sample without interference from others present. A number of techniques are available for this. A component may be inactivated by being destroyed by an enzyme (for example, $\beta$-lactamase for penicillins and cephalosporins) or by the addition of a specific antagonist (for example, para-amino benzoic acid for sulphonamides, or thymidine for trimethoprim). The use of an assay organism which is very resistant to all present but the component antibiotic to be assayed is also a widely used method. The selectivity of such methods allows the estimation of a small concentration of antibiotic in the presence of a much larger concentration of a potentially interfering drug. Unfortunately, selective inactivation is not available for most antibiotics, and it may not be possible to find an assay organism that has sufficient differential sensitivity naturally to allow the reliable assay of a single component. It may then be possible to use an organism which has acquired resistance by induction or by the transference of an R-factor. Unfortunately, such strains may not be stable or are poor in their growth rate and therefore need careful maintenance. Furthermore, the assay must be adequately controlled by the addition of possible interfering drugs, and may be slow.

The method of high-voltage electrophoresis followed by bio-autography, as developed and described in this paper, has the advantage of being independent of many of the above strictures and offers the relatively easy simultaneous quantitation of more than one component. Once the method is set up the electrophoresis is relatively quick and does not add substantially to the total assay time. The main disadvantages are the costs of the equipment (about $f 600$ ) and the running materials. Also, it is not possible to separate all the antibiotics tested by the method as presented, since those with closely similar values would overlap and thus be indistinguishable. The extent to which this occurs with two such antibiotics would depend on their respective $\mathbf{R}_{\mathbf{M}}$ values, concentrations (and thus zone sizes), and for how far they are electrophoresed. Even where $\mathbf{R}_{\mathbf{M}}$ values are identical further procedures can be used to separate the activities. These include the selective inactivation of components by pretreatment with enzymes or by the addition of antagonists to the seed agar, or the use of indicator organisms resistant to an antibiotic. Although these methods could also be applied to conventional assays, the technique comes into its own particularly when more than two antibiotics require separation.

The accuracy of the assay of the three antibiotics chosen for detailed analysis shows that the method is capable of producing results at least as accurate as those used by many laboratories for a single drug. Ninety-five per cent confidence limits of $\pm 25 \%$ are adequate for clinical assays, although they are not easily achieved for a single drug by many laboratories (Reeves and Bywater, 1975). By refinement and practice high accuracies for quality control purposes have been achieved (Lightbown and de Rossi, 1965; Lightbown, 1970). The limiting factor for gentamicin assay by this method was the presence of pear-shaped zones which made it difficult to quantitate the area of inhibition although the results were accurate enough for clinical purposes. The use of more sophisticated techniques for the measurement of zone areas might increase the accuracy of the method for this drug. Where the technique has proved particularly useful is in the assay of antibiotics of closely similar spectra of actions such as fusidic acid, lincomycin, clindamycin, and flucloxacillin in various combinations, mixtures of aminoglycosides, and a mixture containing broad and narrow spectrum antibiotics.

The second main problem for laboratories using microbiological methods is the receipt of specimens for assays containing antibiotics about which they have not been told. We feel that our own laboratory enjoys good co-operation with the clinicians and were therefore surprised and dismayed to find that $35(18 \%)$ of 189 consecutive sera examined contained undisclosed antibiotics. On enquiry the most frequent reasons for this was the recent cessation of a prescription, particularly in patients with poor renal function, or simply an oversight. The presence of these unexpected contaminants represents an obvious hazard to the accuracy of microbiological assays. Occasionally the extraneous drug is revealed by an atypical zone edge or by a pharmacologically impossible result, but misleading information may be obtained on which drug dosage depends. Such is the frequency of unsuspected mixtures that in our own laboratory we are at present screening all sera for assay by high-voltage electrophoresis and bioautography, simultaneously to conventional microbiological assay.

\section{References}

Lightbown, J. W. (1970). Assay of individual antibiotics in drug combinations. In The Control of Chemotherapy, edited by P. J. Watt, pp. 1-9. Livingstone, Edinburgh.

Lightbown, J. W. and de Rossi, P. (1965). The identification and assay of mixtures of antibiotics by electrophoresis in agar gel. Analyst, 90, 89-98.

Reeves, D. S. (1974). Accuracy of gentamicin assays. Postgradute med. J., 50, Suppl. 7, 20-23.

Reeves, D. S. and Bywater M. J. (1975). Quality control of serum gentamicin assays-experience of national surveys. J. Antimicrob. Chemother., 1, 103-116. 
book contains the 32 papers concerned with automation in microbiology and immunology which are grouped in three sections-the applicability of and need for rapid or automated methods in microbiology, antibiotic sensitivity testing, and rapid immunological techniques. Those concerned with new approaches to the identification of micro-organisms appear in a second volume New Approaches to the Identification of Microorganisms.

The first paper, 'Space-Age Automated Analysis' by M. A. Mitz, brings the excitement of science fiction to the description of Viking Lander instrumentation. A contribution on automated radiometric detection of bacteraemia yielded three-quarters of positive cultures in 24 hours, but Pseudomonas aeruginosa appeared later. One of the laboratories used the technique on about 400 aerobic bottles per month, half of the total number of cultures collected from the 720-bed teaching hospital. Flow microfluorimetry has been applied to differential Newcastle disease virus assay and detection of viral antigens. Several automated counting techniques described for colonies on solid media by microvideomat and by automatic image analysis are able to distinguish micro-organisms of different shapes from debris.

The Upjohn Company's Sterile Pharmaceutical Production unit proposes establishing a Royco particle monitor at each critical area of production and interfacing the data output with a dedicated minicomputer. One wonders how a small hospital pharmacy can hope to achieve the environmental quality control for sterile fluid production which only large centralized facilities can achieve at all economically and safely.

Seven papers describe automated sensitivity testing. The differential light scattering pattern from a laser light source recorded as a function of the scattering angle has been automated and the output computerized. Results can be obtained in 90 minutes from exponential phase organisms. This method may eventually be used to observe antibiotic effects on individual cells from the clinical specimen without prior incubation and isolation.

At present, however, the antibiotic susceptibility techniques described depend on preliminary culture to yield single colonies, usually after overnight incubation, so that shortening the time required for reading a result from 6 to 2 hours or less makes little difference to clinical practice.

The third section on rapid immunological techniques includes contributions on IEOP, electroimmunoassays, fluorescent antibody (FA) tests, and pattern recognition. 'The Bioreactor ${ }^{(R)}$, A Robot Technician' in fact describes a system for measurement and transfer of samples, a multichannel high precision serial dilutor, and multichannel high precision microdosage dispenser. It is said to be simple to use and maintain and to have many applications in serology, microbiology, biochemistry, and toxicology.

The application of FA automation may blossom with the impending advent of a serological FA screening test for gonorrhoea.

Costs are rarely mentioned in this book and may have doubled since the symposium was held. However, $\$ 100000$ per pattern recognition instrument suitable for FA work is quoted, so most of us will need to use a microscope for some time to come.

This book gives a fascinating glimpse of things to come in microbiology laboratories in the next decade. Alas, only four of the 64 contributors were from the United Kingdom. The developments described are likely to hasten centralization of certain tests because of the high machine costs and the need to have a computer for rapid data processing. Anyone planning for future needs in microbiology will find much to interest him in this volume.

HILARY J. ANDREWS

Metabolic Disorders of Bone. By C. R. Paterson. (Pp. $373+\mathrm{X}$; illustrated; £8-25.) Blackwell Scientific Publications, Oxford. 1974.

The frequent occurrence of metabolic bone disease is now generally recognized and also the wide variety of ways in which it presents, but few will have been able to keep up with the latest developments in this field. Recent advances, particularly in knowledge of the metabolism of vitamin $D$ and of the physiological activity of its metabolites, have greatly increased understanding of calcium disorders, and in many instances a more rational approach to therapy has evolved as a result. Many patients stand to gain therefore from the timely appearance of Dr. Paterson's book.

The author is to be congratulated on producing such a readable, well-balanced, comprehensive, and up-to-date account of metabolic bone disease. The book starts by outlining the physiological aspects of calcium metabolism which are relevant to clinical problems and then proceeds to discuss the clinical features and investigation of metabolic bone disease. Later chapters deal with hyper- and hypocalcaemia, with hyper- and hypo-parathyroidism, renal stones, osteomalacia and rickets, uraemic osteodystrophy, phosphorus depletion and acidosis, disorders of calcitonin secretion, osteoporosis, Paget's disease, inherited bone disorders, and bone changes accompanying various endocrine disorders. Each topic is critically considered in terms of pathophysiological, clinical, chemical, and radiological features and with regard to treatment and prognosis. The coverage of the literature is remarkable for the bibliography extends to approximately 1400 references and includes a few dated 1974; the author and publisher alike should be justly proud of this achievement.

Although written by a chemical pathologist, this book is clinically orientated and therefore could be read with profit by any physician with an interest in bone disease. It can be highly recommended to the chemical pathologist who will find it an invaluable source of information on the less familiar disorders. It will also prove valuable to those preparing for the MRCP and final MRCPath examinations.

The book is written in a direct and easy style, is well set out, and includes some good quality halftone and other illustrations as well as an adequate index. The text is remarkably free of errors and the production is up to the high standard expected from the publisher.

F. V. FLYNN

\section{Correction}

In Resolution of antibiotic mixtures in serum samples by high-voltage electrophoresis by D. S. Reeves and H. A. Holt (J. clin. Path., 1975, 28, 435-442) the footnote on $p .435$ should read:

Tris-(hydroxy-methyl)-aminomethane $27 \cdot 21 \mathrm{~g}$

Maleic acid $26 \cdot 10 \mathrm{~g}$

Distilled water to 3 litres

Adjust to pH 5.6 with $5 \mathrm{~N} \mathrm{NaOH}$ 